\title{
In Memory of César Ades (1943-2012): The Legacy of Psycho-Ethology
}

\author{
EMMA OTTA \\ University of São Paulo
}

I received an invitation to write an article for a special issue organized by the Revista de Etologia (Current Ethology) in homage to César Ades. I started writing an article in a scientific format, reporting experimental data and following received instructions to use footnotes, to make personal allusions to passages with César in a scientific context. I did not like the result and deleted the text. Rather than follow the conventional format of a scientific paper, I came to the conclusion that it would be more meaningful to be retrospective and present the main issues that guided the work which developed in partnership with César, over thirty years of experience. I could have brought the footnotes to the text body, contrary to instructions, but my homage seemed more significant to me. I hope that this text format will help to promote a reflection on the historical bases of the intersection between the fields of study from Biology and Psychology, to better understand the ways in which evolutionary thought is currently being applied in the study of behavior. My homage to César joins the many others, among which I highlight those made by colleagues and friends from the first generation of Brazilian ethologists. Fernando Ribeiro wrote "Meada de muitos fios" [Skein of many threads], published in the journal Revista de Cultura e Extensão da USP, and Ana Maria Carvalho wrote "Entre teias, bichos, crianças e gente grande, a paixão pela ciência" [Between webs, animals, children and grown ups, the passion for science], published in the journal Memorandum.

\footnotetext{
Department of Experimental Psychology, Institute of Psychology, University of São Paulo. Avenida Professor Mello de Moraes, 1721, São Paulo, SP, CEP: 05508-030, Brazil.
}

\section{From the Alameda Glete Basement to B10}

César graduated in Psychology at USP (University of São Paulo) - he enrolled in 1961 and graduated in 1965. The course was created in 1958, in connection to the Faculty of Philosophy. At that time, classes were given at the Palacete da Alameda Glete [Alameda Glete Mansion] (Figure 1). César attended the Mansion, but spent a lot of time in the Basement. There the first Animal Psychology Laboratory was installed by Prof. Walter Hugo de Andrade Cunha. In addition to studying Tinbergen and Lorenz, the students had the opportunity to put theory into practice, observing the behavior of Atta sexdens through glass tubes and pots. César had the opportunity to study with the founder of Ethology in Brazil. After graduation, he did his $\mathrm{PhD}$ under the orientation of Walter Hugo on the web and hunting behaviour of Argiope argentata spiders. He completed his doctorate in 1973.

In the Glete basement physical space was short in supply, but rich in ideas. Under direct supervision, students learned how to conduct a research, learning the importance of research and evidence, and were contaminated by the pleasure of discovery. It seemed inconceivable to the pioneers that book-based exhibitions about scientific methodology could be appropriate substitutes for laboratory practice. There was a close space of interaction and exchange of ideas among students and between students and teachers. César was in the third year of the undergraduate course and remembers that:

"Sitting at the seminar table, in separate meetings that we scheduled for the evening, Walter, Arno Engelmann and I were discussing the theoretical model of Miller, Galanter and Pribam, as discussed in the book Plans and the Structure of Behavior, a forerunner of cognitivism. Fernando Leite Ribeiro, Katsumaza Hoshino, Alcides Gadotti and I were there planning an experiment on cognitive maps in 

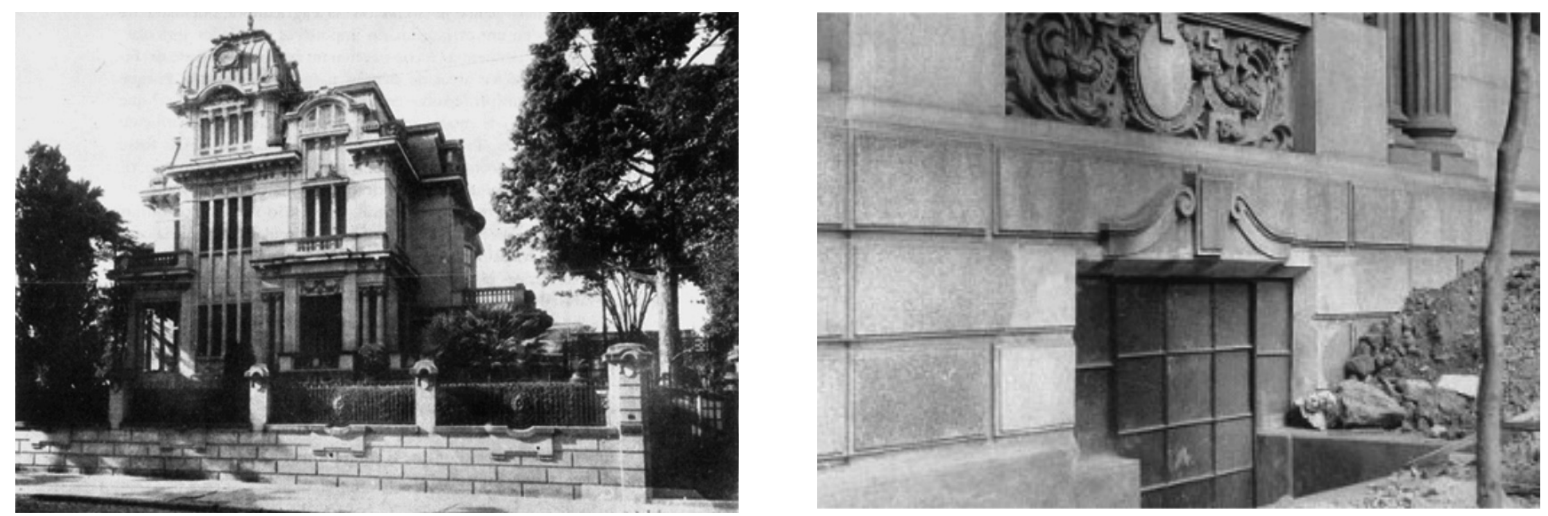

Figure 1. View of the Alameda Glete Mansion where students were given lessons in Psychology and the Basement entrance where the laboratories were. (Source: Bosi, 2011, p. 15-16)

rats, inspired by Edward Tolman, that was only performed much later. In two small rooms, I installed an improvised vivarium and my first lab, in which I was investigating with curiosity the nature of exploratory behavior. The space was small, but extraordinarily dense in ideas, not abandoning for one instant the sense of intellectual achievement." César Ades (2004)

In 1970, the Institute of Psychology was created as an independent unit of education and research. The classes started being given at the campus Armando de Salles Oliveira and the Ethological Laboratories of the Department of Experimental Psychology that were in Block 10. As a graduate student in psychology at USP - I enrolled in 1970 and graduated the course in 1975 - I spent a lot of time in Block 10, where they maintained the tradition brought from the Alameda Glete laboratories of close coexistence and debate of ideas among students and between students and teachers. I was the first master's degree student to be oriented by César (1975-1979) and the third to complete a doctorate under his orientation (1980-1984) at the Institute of Psychology at USP.

\section{"Comparative" Animal Psychology}

At the beginning of my postgraduate studies it was clear that the scientific study of behavior in the international arena was divided between Ethology, which developed mainly in Europe, and behavioristic Psychology, which developed mainly in the U.S.A. Ethologists were interested in the phylogeny and function of behavior and from this perspective they studied proximate causes and ontogeny of behavior

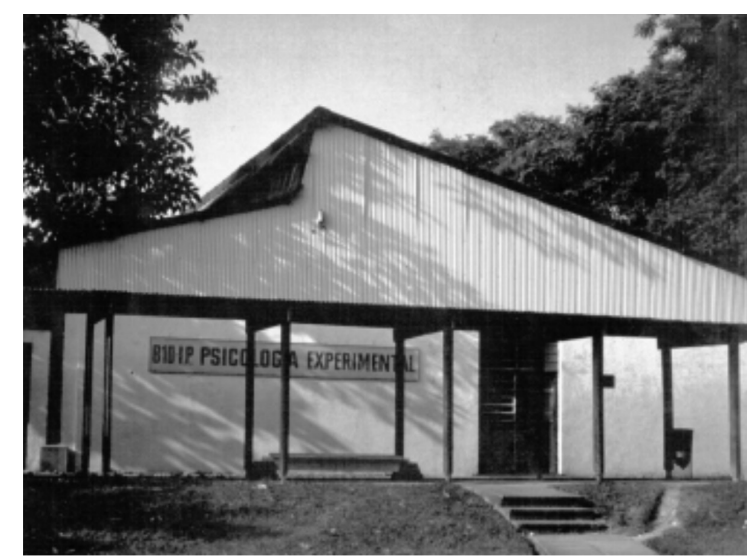

Figure 2. Block 10 where the Laboratories of Ethology were. (Photograph by César Ades)

in a diverse number of animal species (from spiders to non-human primates and humans) in the field and in the laboratory, with an emphasis on behavior linked to survival. The focus of the behaviorists was the study of learning, seeking to reach the general principles, based on the study of a small number of animal species in controlled laboratory conditions (usually rats and pigeons in Skinner boxes).

Criticisms were made on Comparative Animal Psychology. Frank Beach, President of the $6^{\text {th }}$ Division of the American Psychological Association, published his inaugural address as president of this division of the APA in 1950, in the American Psychologist, with the title "The snark was a boojum". He starts his provocative article referring to Lewis Carroll's 1874 poem "The hunting of the Snark, which tells with humour the impossible voyage of an improbable crew to find an inconceivable creature. The hunt is dangerous because, if the Snark is a Boojum, the person sudden- 
ly disappears and is never found again. Continuing in his humorous criticism he draws upon the Pied Piper of Hamelin. A giant rat takes the place of the Piper and attracts researchers to a river where they drown themselves. His criticism refers to the limited number of investigated species and investigated problems by Animal Psychology of the time, meaning that it did not deserve the name comparative.

There is lots of presented evidence of specializations in the field of learning. For example, Keller Breland and Marian Breland (1961), when seeking to apply, for commercial purposes, the principles of experimental behavior analysis, when training animals for commercials and TV shows, found results that led them to publish an article entitled "the misbehavior of organisms" in reference to the classic "The Behavior of Organisms" by their teacher B. F. Skinner, 1938. They trained around 6,000 subjects from 38 species including cockatoos, chickens, pigs, raccoons, skunks and whales. They often incorporated failures as an aspect of the show, like the dancing chicken. The chicken should enter the stage, trigger a device that played a song, climb on the disc and leave the stage in order to receive reinforcement. The dancing chicken scraped the ground, which resulted in postponement of the reinforcement and the bad behavior became increasingly more intense throughout the training. Over the course of a day's presentation, for about three hours, one chicken had made about 10,000 practically identical unnecessary responses. Pigs that should put coins in a pig safe, to convey the idea of savings, at the beginning of training behaved according to the script. But during the training they began to misbehave. They increasingly took longer to drop the coin, they rubbed the coin on the ground, and they tossed it into the air. Changing the chicken and changing the pig, the problem repeated itself. The Brelands created the concept of Instinctive Drift to designate the tendency of an animal to revert to instinctive behaviors at the expense of learned behavior, even if doing this slows or prevents reinforcement.

"The implication from the point of view of Lorenz is that the phenomena of learning per se are just the tip of the iceberg." (Schwartz, 1974, p. 195)

Criticisms like those made by Frank Beach led to a movement whose production was organized in two books: Constraints on Learning, edited by English ethologist Robert Hinde (1970), and Biological
Boundaries on Learning, edited by American experimental psychologist Martin Seligman (1972). We can say that this movement marked a return invitation to nature (Schwartz, 1974), questioning the premise of equipotentiality and reflection about specialized learning skills that may have evolved to deal with special circumstances that the animals found in their natural habitat (Domjan \& Galef, 1983; Bussab \& Ribeiro, 1998). In place of the premise of equipotentiality, the notion of prepared learning was suggested, according to which organisms are biologically equipped (prepared) to make some associations and ill-equipped to make others (contra-prepared). In the middle are arbitrary associations (unprepared) traditionally studied in Experimental Psychology laboratories.

\section{Learning and Motivation viewed from the ecological perspective}

César closely followed all of these debates and controversies. In an interview with Renato Kinuchi and Mauricio Ramos (2011), he commented

\footnotetext{
"It is significant that my contact with animal behavior, upon graduation, had been provided by both the aspect of learning and cognition and the instinctive mechanisms. The possibility that both could be integrated into a unified conception regarding behavior has already constituted cause for reflection."
}

The psycho-ethological approach offers this possibility of integration. In his article entitled "A psycho-ethological perspective for the study of animal behavior", César explains the programmatic points from this perspective:

"Although they cross each other, Ethology (and Behavioral Ecology) and Experimental Psychology have followed separated paths. An integrated psycho-ethological approach to the basic behavioral processes is argued here, with the following programmatic points: 1) the choice of ecologically relevant behavior (functional systems) as an initial focus of analysis; 2) the explicit use of the laboratory situation as a model of natural contexts and 3) the study of inter-specific differences within an ecological framework of reference. This approach has advantages as a generator of research and as a source of evidence for a general theory of animal behavior." Ades, (1986, p. 20) 
I want to highlight the pioneering spirit of early Brazilian ethologists, under the guidance of Walter Hugo Cunha de Andrade (2004), in dealing with motivation and emotion when these issues seemed taboo by those who devoted themselves to the scientific study of animal behavior. Walter speaks about fear as a motivational state in Paratrechina fulva, in his paradigmatic article entitled "On the panic reactions of ants to a crushed conspecific: a contribution to a psychoethology of fear".

In his article entitled "Animal motivation: the classic equilibration from an ecological perspective", César speaks about the ecological matrix of motivated behaviors, critically examining the idea of equilibration, mainly in the form of homeostasis. $\mathrm{He}$ argues that motivational behavior analysis should be based on the investigation of environmentally relevant behavior, in several species.

"I was strongly contesting the movement of 'biological constraints on learning' (Hinde \& Stevenson-Hinde, 1973; Ades, 1974) when I realized that biological constraints (...) also exist in the case of the motivational aspects of behavior, marking their presence even more drastically. The bee that collects nectar to take to the hive where it will have a collective use, the tyrant flycatcher bird perched looking for passing insects, the sea slug that attacks other molluscs by slowly boring into their shells, the ants harvesting leaves and petals for a sponge which will cultivate fungus, the neuropteran larva that traps ants thanks to its crater in the sand, the chaffinch that uses a stick to dislodge hidden larvae in the cavities of a tree trunk, the lionesses that use group strategy to chase and capture zebras and other animals of a certain size, the coyotes who defend a carrion, etc. are examples, among a thousand others, expressing existing variability, not only in the 'appetitive' phase of behavioral sequences, like during feeding times and alertness cycles. I once gave to the idea a radical expression: 'animals from different habitats are subject to the action of diverse motivational variables' (Ribeiro \& Ades, 1975). It seemed important at the time, as it still does, to insist on the consideration of 'motivational relativism', to resist the trend - in current psychological research - to seek, from experiments like deprivation and satiation, a general model of motivation." (Ades, 1985, pp)

It was in this context of ideas that I proposed the study of hamster feeding and storage behavior
(Mesocricetus auratus). The proposal resulted in research conducted under Cesar's supervision from 1980 to 1984 , showing the paradoxical reaction of this species in response to food deprivation compared to that of the rat, and it was this that resulted in my doctoral thesis (Otta, 1984) released in scientific meetings and published in the Proceedings of the $1^{\text {st }}$ Meeting of Ethology (Otta \& Ades, 1983), the $36^{\text {th }}$ SBPC (Brazilian Society for Scientific Progress) (Otta \& Ades, 1984) and the $14^{\text {th }}$ Annual Meeting of the Brazilian Society of Psychology (Otta \& Camargo, 1983). In his article "Animal motivation: the classic equilibration from the ecological perspective", César concludes:

\footnotetext{
"The hamster that keeps an unchanged feeding pace - instead of increasing it, in the face of shortage - poses a challenge to models derived from the classical idea of equilibration. I applaud the search for reasons for the apparent paradox and ultimately refer to the natural circumstances in which it was selected by their species. In addition, be aware of the possibility that similar factors are acting even in the case of animals with regulation mechanisms that are more 'tuned', from the point of view of ingestive behavior, such as in the rat. What was previously considered as a discrepancy and 'curious' aspect of behavior is no longer the case when broader theoretical schedules are created, as it becomes the basis of a necessary explanation." (Ades, 1985, p. 154)
}

It is worth noting that this theme is still current. This can be verified when Bartness and Demas (2004) comment, regarding feeding motivation, that despite the considerable knowledge gained from the study of rats and mice and humans, many fundamental questions have not been satisfactorily clarified. They argue that useful lessons can be learned through the study of 'nature' experiments (i.e. typical food ingestion behavior of the species which were molded by evolution occurring in the real world and in many cases may be conveniently studied in the laboratory).

"Although one might envision that the subsequent feeding response to food deprivation is a highly conserved behavior across most, if not all species, this is not the case. For example, hamster species differ in that they do not overeat after deprivation (...) Why don't hamsters overeat after deprivation and how is this an adaptive response" (Bartness \& Demas, 2004, p. 425) 


\section{Student-Researcher Training}

For 30 years, I had the privilege of administering the discipline "PSE 1444 Motivation and Emotion" with César for undergraduate students in Psychology. Theoretically, the main contribution of the discipline can be synthesized in the following excerpt from the inaugural address to the 19th chair of the São Paulo Psychology Academy entitled "Exploring animal behavior", in which Césarl summed up his legacy:

"Darwinistically speaking, I stress the importance of an epistemology that places psychological issues in a broader context, which is biology and evolutionary thinking. There is no recipe for this integration, it arises when specialists from different areas realize that their understanding will be broader and more creative if they converge. A broader construction and a review of the theoretical schemes depend on these partial efforts, an updated epistemology. This is my message." (Ades, 2009)

César gave great importance to the practical part of the discipline "PSE 1444 Motivation and Emotion", preserving the legacy of the Alameda Glete Basement. We use computers instead of mimeographs to produce instructions and teach students how to make bibliographical reviews in the Web of Science, but the fundamental principles were already all there in the Glete Basement. I hope that they will continue to guide new teachers on the importance of fundamental scientific training in professional training. As one can see in these words from Walter Cunha:

"The students received very strict mimeographed instructions. According to them, in pairs they should choose to replicate some experiments from recent psychological literature (for example, the American Journal of Psychology or of the Journal of Experimental Psychology), copies of which were provided to them in English. They should then perform another experiment, but from their own original design, on the subject from the first experiment. To complement their work, they should write a scientific article about the experiment in an form suitable for publication in accor-

I http://citrus.uspnet.usp.br/cmip/sites/default/files/ Depoimentos_livro_0.pdf

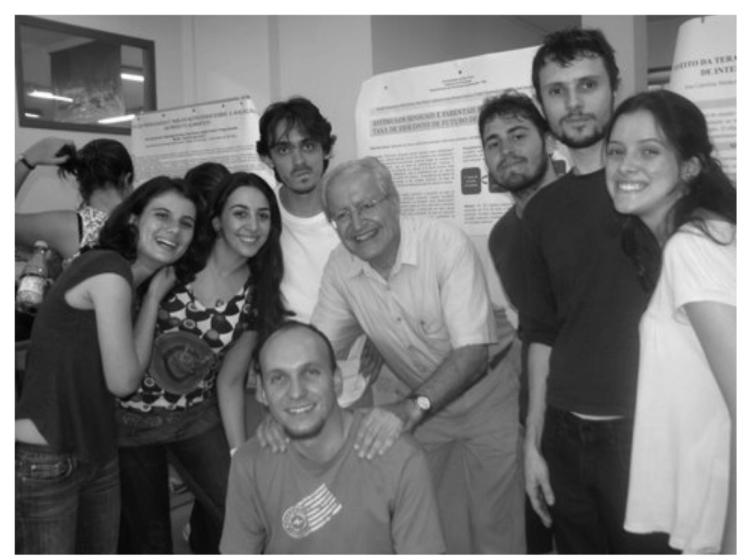

Figure 3. Photo of the last Mini-Congress organized by César.

dance with the standards recommended by the American Psychological Association (i.e., divided into an introduction, purpose, method, results, discussion, conclusion and references). A translation of these standards was also provided to them. The experiments dealt with topics on psychology of perception, motivation and learning."

I remember the excitement and bustle of the students performing the work. The young women, especially, for those tasks that required carpentry which they were certainly unfamiliar with, set themselves to work with great rhythm, usually with an air of fun. The students should bring their 'experimental subjects', recruited among friends, colleagues and acquaintances, or should take turns to subject themselves among the various experiments. Today, I think the discipline demanded too much from this level of students, but, nevertheless, I may have managed to achieve the essentials: passing them the idea of the importance of research and of evidence and, who knows, instill in some among them the pleasure of discovery. It seemed to me then, as it does now, inconceivable that, as unfortunately happens in most subsequently created psychology courses, entirely book-based exhibitions on 'scientific methodology' could be taken as an 'appropriate' and (certainly much more important for schools) cheaper substitute for laboratory practices."

(Walter Hugo de Andrade Cunha, interview with César Ades)

The pioneers thought it of paramount importance that this teaching was not entirely book-based and that it encouraged real investigative activities. 
This is a principle that we follow today. Below is a photo of the last Mini-Congress for the Motivation and Emotion discipline organized by César.

In an email sent to me on February 18, 2011 he commented:

"Our course has had a role of exceptional practical importance for Psychology students. In a paper published in the first issue of Psychology: Science and Profession I stressed that research training was comprehension training ${ }^{2}$. The projects that the students have done, over the many years of the discipline, are a cause for contentment. Through them, and this has always been the idea, it was our intention to give the student a sense of psychological research, demystifying stereotypes relating to experimentation, showing that it is possible to be (up to a certain point) rigorous in interesting subjects."

\section{In conclusion}

I conclude this retrospective in homage to César remembering his good humour. He taught me that professional seriousness and good humour can go together. We know that in Psychology negative emotions and moods such as anger, anxiety and sadness were studied much more than positive moods and emotions, such as joy, gratitude and serenity. We are learning that the study and the cultivation of positive emotions is not a frivolous venture and deserves more attention from us. ${ }^{3}$ Positive emotions result in the expansion of cognitive states, as opposed to a "tunnel vision", in which states of anxiety narrow the focus of attention. The teacher-researcher César Ades was committed to the expansion of students' cognitive states, helping them find positive meaning in the present circumstances, finding positive aspects in adversity, giving them meaning and pointing out constructive ways of problem solving. It is only in this way we can collectively and forcefully face the challenges of the $21^{\text {st }}$ century. Negative emotions are adaptive in facing short-term threats, while positive emotions increase the attention and encourage

2 ADES, C. (1981). Treino em pesquisa, treino em compreensão. Psicologia Ciência e Profissão, v. 1, p. 107-140.

3 Barbara L. Fredrickson site: http://www.unc.edu/ peplab/publications.html cognitive flexibility, which potentially will ensure our long-term success as a group. César contaminated us with his smile and, without us realizing, helped us to see the wood through the trees and to avoid tunnelled visions ${ }^{4}$.

Our area of study today presents itself in rapid development, but also has become increasingly specialized over the last few decades: Psycho-Ethology, Ethology, Human Ethology, Evolutionary Psychology, Animal Cognition, Behavioral Ecology, Behavioral Evolution, Neuroethology, Applied and Conservationist Ethology. Sara J. Shettleworth (2009) is optimistic. In an article whose title is a question:

"Is the snark still a boojum?"

concludes that:

"The last 10-15 years have seen many new developments, and a recent survey like Beach's reveals a very different picture. Not only are many more species being studied, contributions by researchers from different backgrounds are increasing, and research on comparative cognition is better connected with developmental psychology, behavioral neuroscience, primatology, behavioral ecology, and other fields.” (Shettleworth, 2009, p. 210)

Others are more skeptical. While recognizing that much factual and theoretical progress has been made in each of the new specialties, Jerry Hogan (personal communication) argues that "specialization has also had a price, with the reduction in communication between the specialties. ${ }^{5}$ Scientific history is full of examples of controversies due to the difficulty of a group of scientists in understanding the terms and concepts that another group uses. Communication between scientists from different specialties is necessary and will promote new insights". It seems to me that reflecting on the legacy given to us from

\footnotetext{
4 Johnson, K. J., Waugh, C. E. \& Fredrickson, B. L. (2010). Smile to see the forest: Facially expressed positive emotions broaden cognition. Cognition and Emotion, 24, 299-321.

5 The ethologist Jerry A. Hogan is a Distinguished Professor from the Department of Psychology at the University of Toronto, Canada. He has contributed to the study of animal behavior with research on motivational systems. I continued a visiting Professor's project, which was started by César Ades, to promote his coming to USP (University of São Paulo through the Institute of Advanced Studies in 2013-2014.
} 
the Alameda Glete Basement through César Ades can be inspiring in this regard.

César had a natural ability to build bridges between people and overcome unnecessary theoretical divisions. He liked to talk. I think he recovered elements that must have been central in human evolution.

"Our cultural evolution (and maybe even our cerebral evolution ...) was guided by eras of meetings around campfires, sharing our deepest perspectives about the world in which we live. The best education must rekindle the spirit of the intellectual campfire to the modern classroom." (Panksepp, 1998)

\section{References}

Ades, C. (1973). A teia e a caça da aranha Argiope argentata. Doutorado em Psicologia (Experimental Psychology). University of São Paulo, USP, Brazil. (Supervisor: Walter Hugo de Andrade Cunha).

Ades, C. (1981). Treino em pesquisa, treino em compreensão. Psicologia Ciência e Profissão, v. 1, p. 107-140.

Ades, C. (1985). Motivação animal: da equilibração clássica à perspectiva ecológica. Psychology: Teoria $e$ Pesquisa, 1(2), 147-157.

Ades, C. (1986). Uma perspectiva psicoetológica para o estudo do comportamento animal. Boletim de Psicologia, 36(85), 20-30.

Ades, C. (2004) O Tempo Vivo da Memória. Grupo Figueira da Glete: Nossa História. http://www.figueiradaglete.com. br/cesar_ades_psicol_exp.html

Bartness, T. J. \& Demas, G. E. (2004). Studies of food intake: lessons from nontraditionally studied species. In Edward Stricker and Stephen Woods (eds.) Neurobiology of Food and Fluid Intake, 2. ed., Volume 14 of Handbook of Behavioral Neurobiology. New York: Kluwer Academic / Plenum Publishers. pp. 423-467.

Beach, F.A. (1950). The snark was a boojum. American Psychologist, 5, 115-124.

Bosi, E. (2011). Memórias da Psicologia. In Otta, E., Oliveira, P. de S. e Mannini, C. R. B. B. (eds.). 40 anos do Instituto de Psicologia da Universidade de São Paulo. São Paulo: EDUSP.

Breland, K. and Breland, M. (1961). The misbehavior of organisms. American Psychologist, 16, 681-684.

Bussab, V. S. \& Ribeiro, F. L. (1998). Biologicamente cultural. In: Lídio de Souza et alli (org.) Psicologia: reflexões (im)pertinentes. São Paulo, Casa do Psicólogo.

Carvalho, A. M. A. (2012). César Ades (08/01/1943 14/03/2012): entre teias, bichos, crianças e gente grande, a paixão pela ciência. Memorandum, 22, 226241.

Cunha, W. H. de A. Centro de Lógica, Epistemologia e História da Ciência. Arquivos Históricos. http://www. cle.unicamp.br/arquivoshistoricos $/$ ?destino $=\mathrm{WHu}$ go_principal.html

Domjan, M. \& Galef, Jr., B. G. (1983). Biological constraints on instrumental and classical conditioning: Retrospect and prospect. Animal Learning EBehavior, 11 (2), 151-161.

Cunha, W. H. de a. (2004). On the panic reactions of ants to a crushed conspecific: a contribution to a psychoethology of fear. Revista de Etologia, 6(2), 133140.

Hinde, R. A. (1973). Constraints on learning: An introduction to the problem. In R.A. Hinde \& J. Stevenson-Hinde (Eds.), Constraints on learning. London: Academic Press.

Kinouchi, R. R. e Ramos M. de C. (2011). Psicologia e biologia: entrevista com César Ades. Scientiae Studia, 9(1) [cited 2013-01-26], pp. 189-203 . Available from: <http://www.scielo.br/scielo.php?

Otta, E. (1979). Construção de ninho no hamster: uma análise motivacional. Dissertação (Mestrado em Psicologia Experimental) - Universidade de São Paulo. (Orientador: Cesar Ades).

Otta, E. e Ades, (1983) Efeitos da privação sobre o consumo e o armazenamento de alimento, a curto e a longo prazo, no hamster Mesocricetus auratus. In Anais do $1^{\circ}$ Encontro de Etologia, p. 250.

Otta, E. \& Camargo, A. (1983). Regulação de peso corporal em hamsters, após privação e em condições de acesso 
contínuo a alimento. In Anais da $13^{\text {a }}$ Reunião Anual de Psicologia de Ribeirão Preto, Ribeirão Preto, SP. P. 83.

Otta, E. e Ades, C. (1984). Comer e armazenar no hamster Mesocricetus auratus: efeitos a curto e a longo-prazo de privações impostas de alimento. In: Suplemento Ciência e Cultura, Reunião Anual da Sociedade Brasileira para o Progresso da Ciência, 36, São Paulo, p. 975.

Otta, E. (1984). Comer e armazenar no hamster: duas estratégias comportamentais que se integram. Tese (Doutorado em Experimental) - Universidade de São Paulo. (Orientador: Cesar Ades).

Panksepp, J. (1998). Affective Neuroscience: The foundations of human and animal emotions. New York: Oxford University Press.

Ribeiro, F. J. L. (2012). Meada de muitos fios: o legado de César Ades. Revista de Cultura e Extensão da USP, 7 , 15-18.
Schwartz B. (1974). On going back to nature: a review of Seligman and Hager's Biological Boundaries of Learning. Fournal of the Experimental Analysis of Behavior, 21, 183-198.

Seligman, M.E. P., \& Hager, J. L. (Eds.). Biological boundaries of learning. New York: Appleton-Century-Crofts, 1972.

Shettleworth, S. J. (2009). The evolution of comparative cognition: Is the snark still a boojum?. Behavioural Processes, 80 (3), 210-217.

Silverman, H. J. \& Zucker, I. (1976). Absence of post-fast food compensation in the golden hamster (Mesocricetus auratus). Physiology and Behavior, 17, 271-285.

Skinner, B. F. (1938). The Behavior of Organisms: An Experimental Analysis. Cambridge, Massachusetts: B.F. Skinner Foundation.

Received in February 12, 2013 Accepted April 23, 2013 